\title{
Synthesis and Spectroscopic Properties of 2,3-Diphenyl-1,3-thiaza-4-one Heterocycles
}

\author{
Lee J. Silverberg ${ }^{1}$, Carlos N. Pacheco ${ }^{2}$, Anthony Lagalante ${ }^{3}$, Kevin C. Cannon ${ }^{4}$, Joshua T. Bachert ${ }^{1}$, Yiwen Xie ${ }^{1}$, \\ Lucas Baker ${ }^{1}$, J. Austin Bayliff ${ }^{1}$ \\ ${ }^{1}$ Pennsylvania State University, 200 University Drive, Schuylkill Haven, PA, 17972, USA \\ ${ }^{2}$ Pennsylvania State University, University Park Campus, 104 Chemistry Building, Room 14, University Park, \\ PA, 16802, USA \\ ${ }^{3}$ Villanova University, Department of Chemistry, Mendel Science Center, 800 Lancaster Avenue, Villanova, PA, \\ 19085, USA \\ ${ }^{4}$ Pennsylvania State University, Abington Campus, 1600 Woodland Road, Abington, PA, 19001, USA \\ Correspondence: Lee J. Silverberg, Pennsylvania State University, 200 University Drive, Schuylkill Haven, PA, \\ 17972, USA. Tel: 1-570-385-6051.E-mail:1js43@psu.edu
}

Received: September 6, 2015 Accepted: September 21, 2015 Online Published: October 16, 2015

doi:10.5539/ijc.v7n2p150 URL: http://dx.doi.org/10.5539/ijc.v7n2p150

\begin{abstract}
Synthetic and spectroscopic data $\left({ }^{1} \mathrm{H} \quad \mathrm{NMR},{ }^{13} \mathrm{C} \quad \mathrm{NMR}\right.$, IR, UV/Vis) for a series of six 2,3-diphenyl-1,3-thiaza-4-one heterocycles which differ in ring size and substitution is reported. The results show that there are significant differences in spectroscopic signals common to all six compounds. Distinctions can be made among the compounds using the IR absorbance of the $\mathrm{C} 4$ carbonyl and the ${ }^{1} \mathrm{H}$ NMR signal at $\mathrm{C} 2$, and to a lesser extent the ${ }^{13} \mathrm{C}$ NMR signal at $\mathrm{C} 4$ and the $\mathrm{UV} / \mathrm{Vis}$ spectrum.
\end{abstract}

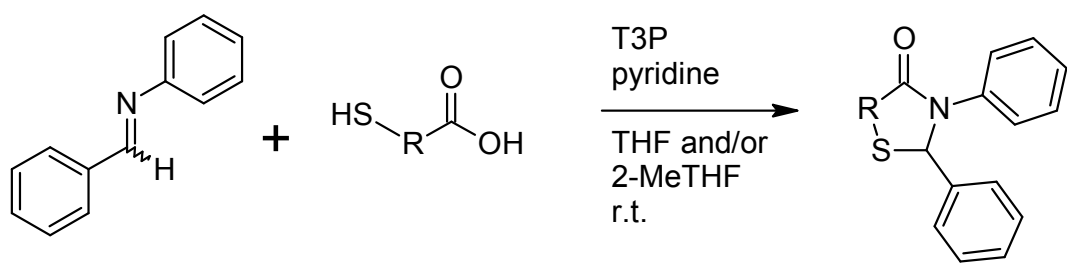

$\mathrm{R}=1,2$, or 3 carbon chain, with or without further substitution

Keywords: heterocycles, spectroscopy, T3P, thiazepanone, thiazinone, thiazolidinone

\section{Introduction}

The five-, six-, and seven-membered 1,3-thiaza-4-one heterocycles (Figure 1) are known for their bioactivity. The five-membered 1,3-thiazolidin-4-ones are known to have a broad array of biological activity (Jain, Vaidya, Ravichandran, Kashaw \& Agrawal, 2012, Abhinit, Ghodke \& Pratima, 2009, Hamama, Ismail, Shaaban \& Zoorob, 2008, Singh, Parmar, Raman \& Stenberg, 1981, Brown, 1961, Tripathi et al., 2014, Prabhakar, Solomon, Gupta \& Katti, 2006). Compounds in this family include active pharmaceuticals thiazolidomycin (anti-streptomyces species), pioglitazone (hypoglycemic for treatment of diabetes), etoziline (anti-hypertensive), and ralitoline (anti-convulsant) (Brown, 1961, Tripathi et al., 2014). The six-membered 1,3-thiazin-4-ones have also often been investigated for their biological activity (Ryabukhin, Korzhavina \& Suzdalez, 1996) and include the anti-anxiety and muscle relaxant drugs chlormezanone (Ryabukhin et al., 1996, Tanaka \& Hirayani, 2005, Surrey, Webb \& Gesler, 1958) and dichlormezanone (Surrey, et al., 1958). The activity of the seven-membered 1,3-thiazepan-4-ones is exemplified by the investigational compound omapatrilat, an ACE/NEP inhibitor that was to be for treatment of high blood pressure (Graul, Leeson \& Castañer, 1999, Tabrizchi, 2001, Robl et al., 1997). 


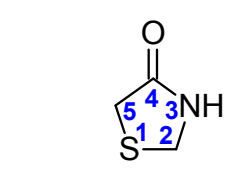

\section{1, 3-thiazolidin-4-one 1, 3-thiazin-4-one}<smiles></smiles><smiles></smiles>

Figure 1.1,3-Thiaza-4-one heterocycles

2,3-Diaryl-1,3-thiazolidin-4-ones can be readily prepared by condensation of a $C$-aryl- $N$-aryl imine with thioglycolic acid 1 (Figure 2) (Jain et al., 2012, Tierney, 1989, Surrey, 1947). Notably, Tierney (1989) has reported that the condensation, in particular the amide bond formation, is slower than when an alkyl group is on the nitrogen.<smiles>[R][R]1ccccc1/N=C/c1ccccc1</smiles>
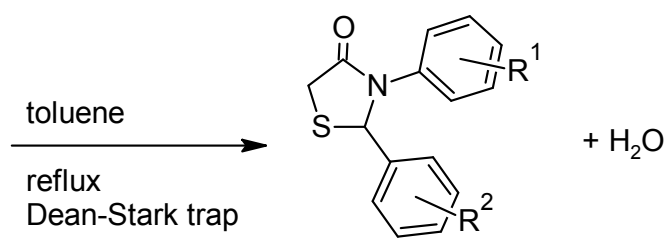

1

Figure 2. Synthesis of 2,3-diaryl-1,3-thiazolidin-4-ones (Jain et al., 2012, Tierney, 1989, Surrey, 1947).

Preparation of the six-membered 1,3-thiazin-4-ones by this method is generally slower than the five-membered rings. Thus, while $N$-alkyl-1,3-thiazin-4-ones can be prepared readily by condensation, the $N$-aryl analogues have proven more elusive. Although Surrey et al. (1958) have reported that condensation of $\mathrm{N}$-benzylideneaniline $\mathbf{2}$ with thioglycolic acid $\mathbf{1}$ could be accomplished, the reaction of $\mathbf{2}$ with 3-mercaptopropionic acid 3 was reported as "unsuccessful" (Figure 3). Loev (1963) has reported that reaction of an $N$-phenyl imine with thiosalicylic acid 5 "failed" (Figure 4), while an $N$-methyl imine succeeded.<smiles>C(=N/c1ccccc1)\c1ccccc1</smiles>

2<smiles>O=C(O)CCS</smiles>

3<smiles>[Y]C(C)(C)C(C)(C)C(=O)O</smiles>

4

Figure 3. "Unsuccessful" preparation of 2,3-diphenyl-2,3,5,6-tetrahydro-4H-1,3-thiazin-4-one 4 reported by Surrey et al. (1958).<smiles>Nc1ccccc1-c1ccc(S)c(C(=O)O)c1</smiles><smiles>[X]C(C)(C)OC(C)(C)CC</smiles>

Figure 4. "Failed" preparation of 3-phenyl-2-( $p$-Cl-phenyl)-2,3-dihydro-4H-1,3-benzothiazin-4-one reported by Loev (1963).

When we started this study, a small number of $N$-aryl-2,3-dihydro-4H-1,3-thiazin-4-ones had been successfully prepared by this approach under a limited number of conditions (Yi et al., 2012, Rajopadhye \& Popp, 1985, Ottenheijm, Vermeulen \& Breuer, 1974, Ottenheijm, Hulshof \& Nivard, 1975, Mogilaiah, Reddy \& Rao, 1999, Metwally, 2013, Joshi, Jain \& Nishith, 1991, Joshi, Dandia \& Ahmed, 1986, Dandia, Singh, Merienne, Morgant \& Loupy, 2003, Dandia, Singh \& Arya, 2004, Dandia, Sharma \& Saha, 1998, Dandia, Saha \& Taneja 1998, Dandia, Saha \& Shivpuri, 1997, Dandia, Saha \& Rani, 1998, Choi et al., 2008, Chen et al., 2012, Arya, Rawat \& 
Sasai, 2012, Green Chem., Arya, Rawat \& Sasai, 2012, J. Fluorine Chem., Zarghi, Zebardast, Daraie \& Hedyati, 2009, Zhou et al., 2008, Srivastava, Haq \& Katti, 2002, Kamel et al., 2010, Dandia, Arya, Sati \& Gautam, 2004, Aissaoui et al., 2012). Some more have been reported since (Qu et al., 2013, Dandia, Singh \& Saini, 2013, Arya, Tomar \& Singh, 2014, Kitsiou, Unsworth, Coulthard \& Taylor, 2014). No synthesis of $\mathrm{N}$-aryl-1,3-thiazepan-4-ones by a condensation of an imine with a thioacid has been reported.

We have recently communicated syntheses and crystal structures of a number of 6- and 7-membered 2,3-diphenyl-1,3-thiaza-4-ones (Yennawar \& Silverberg, 2013, Yennawar \& Silverberg, 2014, Yennawar, Bendinsky, Coyle, Cali \& Silverberg, 2014, Yennawar, Singh \& Silverberg, 2014, Yennawar, Singh \& Silverberg, 2015). In this article, we summarize and update our preparation of the 6- and 7-membered 2,3-diphenyl-1,3-thiaza-4-one heterocycles, and report and compare the spectroscopic properties of these and the 5 -membered analog.

\section{Results}

\subsection{Synthesis}

Similar to the reports by Surrey et al. (1958) and Loev (1963) in which benzene (b.p. $80{ }^{\circ} \mathrm{C}$ ) was used as the solvent, our initial attempts to react $\mathbf{2}$ with either $\mathbf{3}$ or $\mathbf{5}$ by condensation in refluxing toluene (b.p. $110-111^{\circ} \mathrm{C}$ ) or xylenes (b.p. $\sim 140 \quad{ }^{\circ} \mathrm{C}$ ) were unsuccessful, proceeding extremely slowly at best. Reactions using $p$-toluenesulfonic acid catalyst in refluxing toluene (Zarghi et al., 2009), sodium sulfate in dioxane (Kamel et al., 2010), or dicyclohexylcarbodiimide catalysis (Zhou et al., 2008, Srivastava, et al., 2002) were also unsuccessful.

Reasoning that the amide formation would likely be the rate-determining step, we looked to a paper published by Dunetz et al. (2011), which used two equivalents 2,4,6-tripropyl-1,3,5,2,4,6-trioxatriphosphorinane-2,4,6-trioxide (T3P) and four equivalents pyridine for amide formation. When applied to the reaction of $\mathbf{2}$ with $\mathbf{5}$, successful cyclization was achieved at room temperature to give 6. Compound $\mathbf{6}$ has been previously reported (Ponci, Baruffini \& Gialdi, 1963, Kollenz \& Ziegler, 1970, Oae \& Numata, 1974), but not prepared by condensation of $\mathbf{2}$ and $\mathbf{5}$. Shortly after our initial success, Unsworth, Kitsiou \& Taylor (2013) published a paper in which a variety of heterocycles were prepared using T3P at $90{ }^{\circ} \mathrm{C}$, including two examples of $\mathrm{N}$-alkyl-1,3-benzothiazin-4-ones. In 2014, the authors published another paper with more examples, including one with an $N$-aryl group (Kitsiou et al., 2014).

Without any further optimization of the reaction, we have successfully reacted a number of other thioacids with $\mathrm{N}$-benzylideneaniline 2 to prepare six- and seven-membered 2,3-diphenyl-1,3-thiaza-4-one heterocycles (Figure 5 , Table 1). We have previously reported the syntheses and x-ray crystal structures of all products (Yennawar \& Silverberg, 2013, Yennawar \& Silverberg, 2014, Yennawar, Bendinsky et al., 2014, Yennawar, Singh \& Silverberg, 2014, Yennawar, Singh \& Silverberg, 2015). The syntheses of 6, 8 and $\mathbf{1 2}$ have since been repeated and updated procedures and yields are reported here. Thioacid $\mathbf{3}$ reacted to give $\mathbf{4}$, the compound Surrey et al. (1958) had been unable to synthesize. A successful outcome was also achieved with 2-thionicotinic acid 7, which Dandia et al. (2004) reported as unreactive with an $N$-aryl imine, under a variety of conditions and catalysts, without microwave radiation. Also notable is $N$-acetyl-L-cysteine $\mathbf{9}$, which reacted to give the cis diastereomer $\mathbf{1 0}$ as the major product in reasonable yield. Thioacid $\mathbf{1 1}$ worked as well, giving the synthetically challenging seven-membered ring 12. In fact, every thioacid attempted to this point has worked in this reaction. Products in each case were purified by column chromatography and/or recrystallization. The reader may note that in most cases tetrahydrofuran and 2-methyltetrahydrofuran were both used as solvents (T3P came as a 50\% solution in 2-methyltetrahydrofuran, and THF was additionally added to the reaction) while in the later preparation of $\mathbf{1 2}$ only 2-methyltetrahydrofuran was used. It does not appear to make any difference in the reaction, and in our current work we are using only 2-methyltetrahydrofuran. Yields and reaction times were not optimized.<smiles>C(=N/c1ccccc1)\c1ccccc1</smiles>
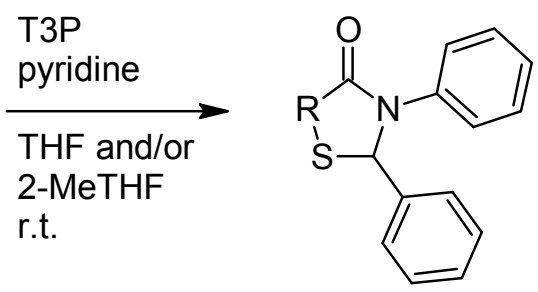

Figure 5. Synthesis of 1,3-thiaza-4-one heterocycles. 
Table 1. 1,3-Thiaza-4-one heterocycles prepared. Yields and reaction times were not optimized.

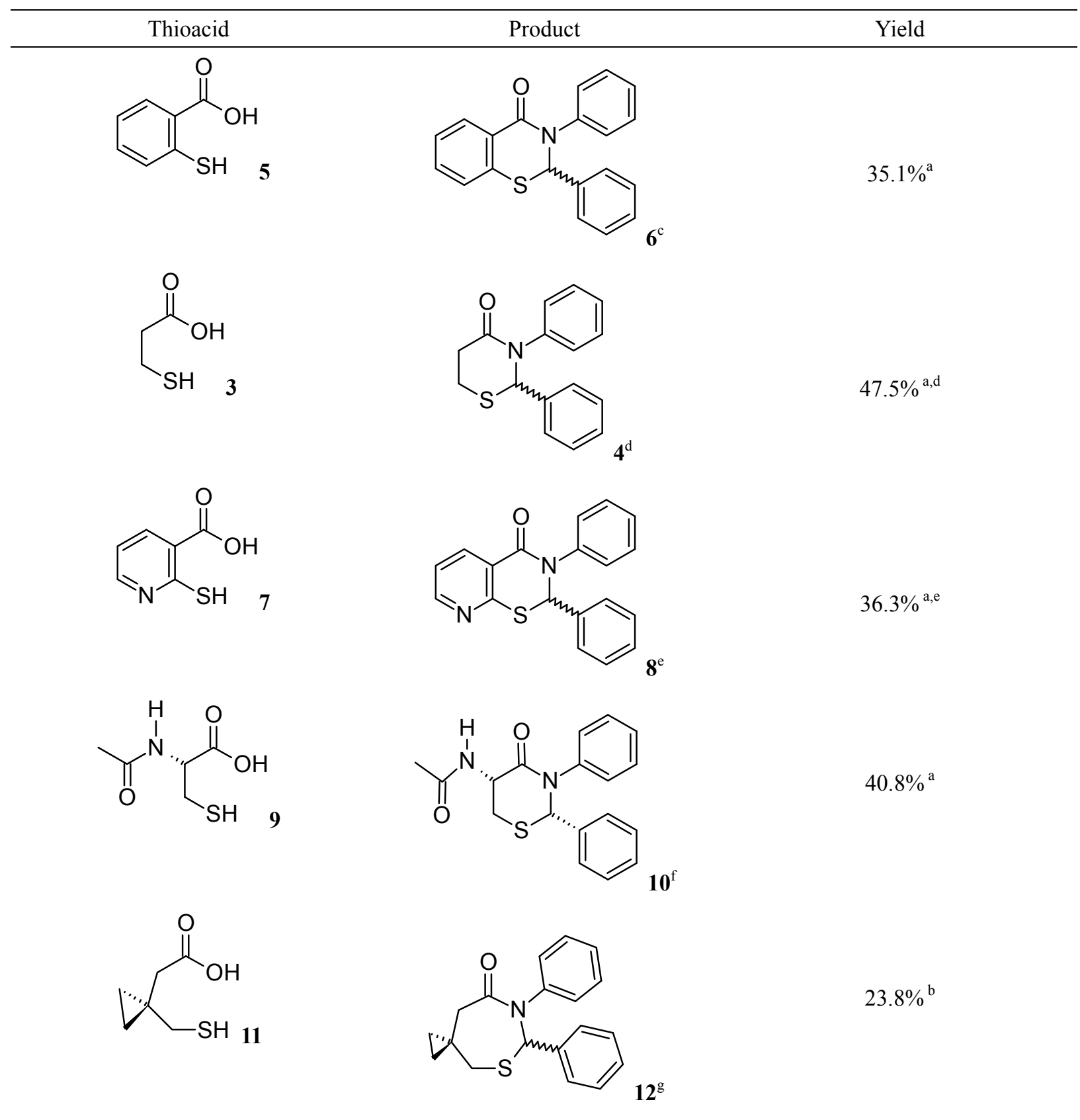

a) Yield of isolated material after chromatography of crude product and then recrystallization; b) Yield of isolated material after recrystallization from crude product; c) Yennawar, Bendinsky et al., 2014, Ponci et al., 1963, Kollenz \& Ziegler, 1970, Oae \& Numata, 1974; d) Yennawar, Tierney \& Silverberg, 2014; e) Yennawar, Singh \& Silverberg, 2014; f) Yennawar, Singh \& Silverberg, 2015; g) Yennawar \& Silverberg, 2013.

Unsworth et al. (2013) have proposed a mechanism for T3P-promoted 1,3-benzothiazin-4-one formation in which the acid is rapidly activated by reaction with T3P, and then is attacked by the imine nitrogen to give an iminium ion. On the other hand, it has been shown that 1,3-thiazolidin-4-one formation without a promoter occurs by initial attack of sulfur on the imine carbon (Tierney, 1989, Surrey, 1947). Reaction of 2 with 5 in THF, without T3P/2-methyltetrahydrofuran and with or without pyridine, gave no apparent reaction (Figure 6). This supports the mechanism proposed by Unsworth et al. 


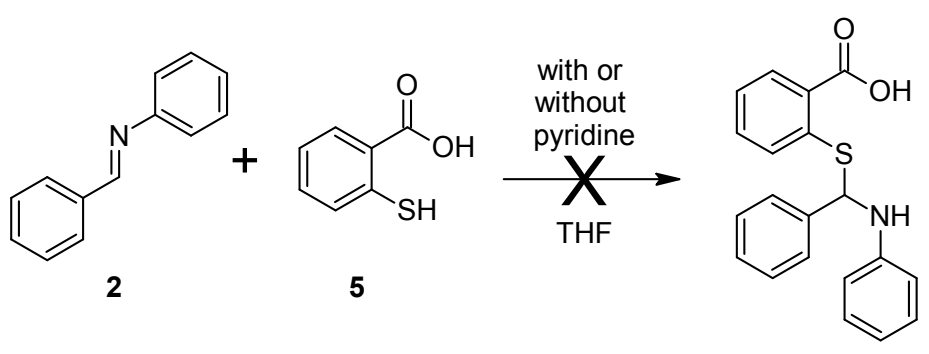

Figure 6. Attempted reaction of $\mathbf{2}$ with $\mathbf{5}$ without T3P.

\subsection{Spectroscopic Properties}

Each of the compounds in Table 1, along with the known 2,3-diphenyl-1,3-thiazolidin-4-one 13 (Tierney, 1989), has been analyzed by Nuclear Magnetic Resonance (NMR), Infrared (IR), and Ultraviolet-Visible (UV-Vis) Spectroscopy. ${ }^{1} \mathrm{H}$ NMR, ${ }^{13} \mathrm{C}$ NMR, and IR spectra of $\mathbf{1 3}$ have been previously reported (Woolston et al., 1992, Woolston, Lee \& Swinbourne, 1993, Magn. Reson. Chem., Tierney et al., 1996, Woolston, Lee \& Swinbourne, 1993, Phosphorus, Sulfur, and Silicon and the Related Elements), but have been performed again in this study to keep the comparison consistent. The data are in good agreement. An x-ray crystal structure of $\mathbf{1 3}$ was also previously reported (Yennawar \& Silverberg, 2014). As mentioned above, 6 is also a known compound, but no spectral data has been previously reported (Ponci et al., 1963, Kollenz \& Ziegler, 1970, Oae \& Numata, 1974. Badea et al. (1998) claimed the compound but their IR and NMR data does not match ours, and their melting point $\left(230-232^{\circ} \mathrm{C}\right)$ is much higher than all other reports.

The results are compiled in Table 2, with only key signals common to each product compared. Full spectral data is provided in the Experimental Section.

Table 2. Comparison of key spectroscopic signals.

\begin{tabular}{|c|c|c|c|c|c|}
\hline Compound & $\begin{array}{c}{ }^{1} \mathrm{H} \text { NMR Chemical } \\
\text { Shifts at } \mathrm{C} 2(\mathrm{ppm} \text {, } \\
\left.\mathrm{CDCl}_{3}\right)\end{array}$ & $\begin{array}{c}{ }^{13} \mathrm{C} \text { NMR } \\
\text { Chemical Shifts } \\
\text { at } \mathrm{C} 2(\mathrm{ppm} \text {, } \\
\left.\mathrm{CDCl}_{3}\right)\end{array}$ & $\begin{array}{c}{ }^{13} \mathrm{C} \mathrm{NMR} \\
\text { Chemical Shifts } \\
\text { at } \mathrm{C} 4(\mathrm{ppm} \text {, } \\
\left.\mathrm{CDCl}_{3}\right)\end{array}$ & $\begin{array}{l}\text { IR Absorbance of } \\
\text { Carbonyls }\left(\mathrm{cm}^{-1}\right)\end{array}$ & $\begin{array}{c}\text { UV-Vis } \\
\text { Absorbance } \\
\lambda_{\max }(\mathrm{nm})\end{array}$ \\
\hline & $\begin{array}{c}6.12(\mathrm{~s}, 1 \mathrm{H}) \\
\left(\text { lit.: } 6.08,{ }^{\mathrm{c}} 6.09 .{ }^{\mathrm{e}}\right)\end{array}$ & $\begin{array}{c}65.8 \\
\left(\text { lit.: } 65.84,^{\mathrm{d}}\right. \\
\left.65.57 .{ }^{\mathrm{e}}\right)\end{array}$ & $\begin{array}{c}171.3 \\
\left(\text { lit.: } 171.22{ }^{\mathrm{d}}\right. \\
170.92 .^{\mathrm{e}}{ }^{\mathrm{C}}\end{array}$ & $\begin{array}{c}\text { C4: } 1668.8 \\
\left.\text { (lit.: 1670.4. }{ }^{f}\right)\end{array}$ & 272 (methanol) \\
\hline $13^{b, c, d, e, f}$ & & & & & \\
\hline 4 & $5.91(\mathrm{~s})$ & 65.8 & 169.7 & C4: 1633.2 & 272 (methanol) \\
\hline 10 & $6.09(\mathrm{~s})$ & 63.8 & 170.0 or $170.5^{\mathrm{a}}$ & $\begin{array}{c}\text { C4: } 1643.2 \\
\text { Sidechain: } 1678.1\end{array}$ & 272 (methanol) \\
\hline 6 & $6.07(\mathrm{~s}, 1 \mathrm{H})$ & 65.3 & 163.8 & C4: 1682.3 & $\begin{array}{c}272 \\
\text { (cyclohexane) }\end{array}$ \\
\hline 8 & $6.17(\mathrm{~s}, 1 \mathrm{H})$ & 64.6 & 163.4 & C4: 1650.7 & $\begin{array}{c}284 \text { and } 308, \\
\text { nearly equal } \\
\text { absorbance } \\
\text { (methanol) }\end{array}$ \\
\hline 12 & $6.17(\mathrm{~s}, 1 \mathrm{H}))$ & 68.7 & 174.2 & C4: 1646.6 & 268 (methanol) \\
\hline
\end{tabular}

a) There is a second carbonyl on the sidechain at C5; b) Yennawar \& Silverberg, 2014; c) Woolston et al., 1992;

d) Woolston, Lee \& Swinbourne, 1993, Mag. Reson. Chem.; e) Tierney et al., 1996; f) Woolston, Lee \& Swinbourne, 1993, Phosphorus, Sulfur, and Silicon and the Related Elements. 


\section{Discussion}

\section{$3.1^{1} H N M R$}

The signal that is common to all of the structures in Table 2 is the proton at $\mathrm{C} 2$, a carbon which is also connected to the sulfur, the ring nitrogen, and a phenyl ring. In comparing the 5-, 6-, and 7-membered rings $(\mathbf{1 3}, \mathbf{4}$, and $\mathbf{1 2})$, the most upfield resonance was at $5.91 \mathrm{ppm}$ in $\mathbf{4}, \geq 0.2 \mathrm{ppm}$ less than in $\mathbf{1 3}$ and $\mathbf{1 2}$. The signal in compound $\mathbf{1 2}$ was $0.05 \mathrm{ppm}$ more downfield than $\mathbf{1 3}$. Thus the $\mathrm{C} 2$ signal appears to be useful diagnostically for distinguishing between the thiazolidinone and thiazinone rings, and possibly between the thiazinone and thiazepanone rings, although this is less certain because of the presence of the cyclopropyl substituent at C6.

The fused benzene ring in 6 moved the $\mathrm{C} 2$ resonance downfield by $0.18 \mathrm{ppm}$ compared to 4 . The pyridine ring in 8 moved the signal another $0.1 \mathrm{ppm}$ farther downfield than in $\mathbf{6}$. Thus $\mathbf{6 , 4}, \mathbf{4}$ and $\mathbf{8}$ are distinguishable according to the $\mathrm{C} 2$ resonance.

Having a cis $\mathrm{N}$-acetyl group at $\mathrm{C} 5$ moved the $\mathrm{C} 2$ resonance in $\mathbf{1 0}$ downfield, as compared to $\mathbf{4}$, to 6.09 . A ${ }^{1} \mathrm{H}-{ }^{1} \mathrm{H}-\mathrm{COSY}$ NMR experiment in $\mathrm{CD}_{2} \mathrm{Cl}_{2}$ showed that the protons at $\mathrm{C} 5$ and $\mathrm{C} 6$ were all coupled to each other (Figure 7). Coupling of the proton on $\mathrm{C} 5$ was also seen with the adjacent $\mathrm{NH}(6.75 \mathrm{ppm})$. Although the proton at $\mathrm{C} 2$ appeared as a singlet in the COSY, some coupling was seen with one of the protons ( $\mathrm{dd}$ at $3.5 \mathrm{ppm}$ at room temp.) at C6. Processing of the NMR data with resolution enhancement (Figure 8) did in fact show small couplings on $\mathrm{C} 2$ (dt, $6.1 \mathrm{ppm}$ ) and one of the $\mathrm{C} 6$ protons (ddd, $3.5 \mathrm{ppm}$ ).

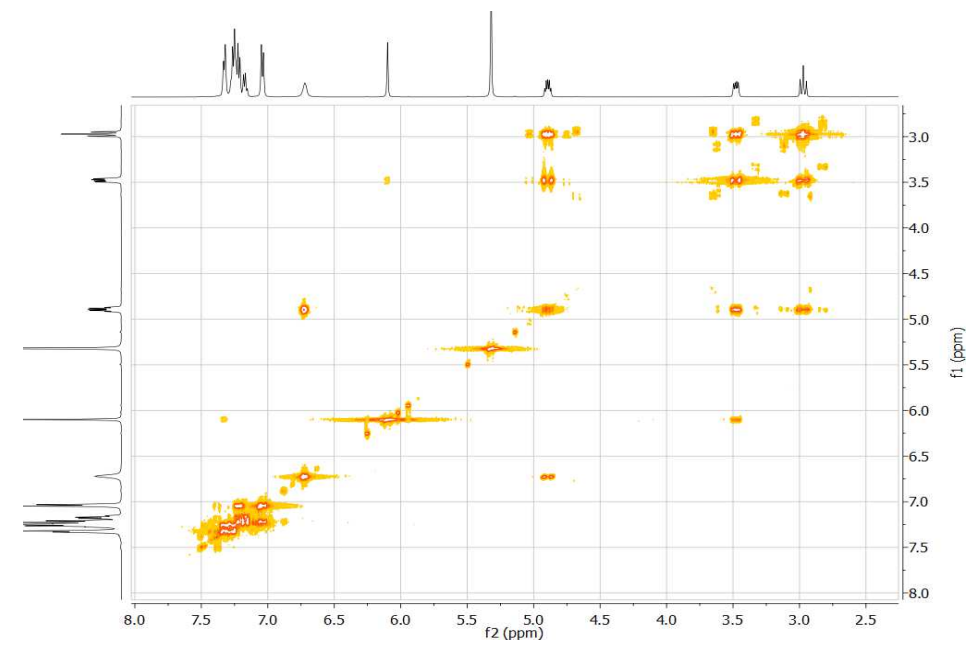

Figure 7. ${ }^{1} \mathrm{H}-{ }^{1} \mathrm{H}-\mathrm{COSY}$ of $\mathbf{1 0}$ in $\mathrm{CD}_{2} \mathrm{Cl}_{2}$ at room temperature.

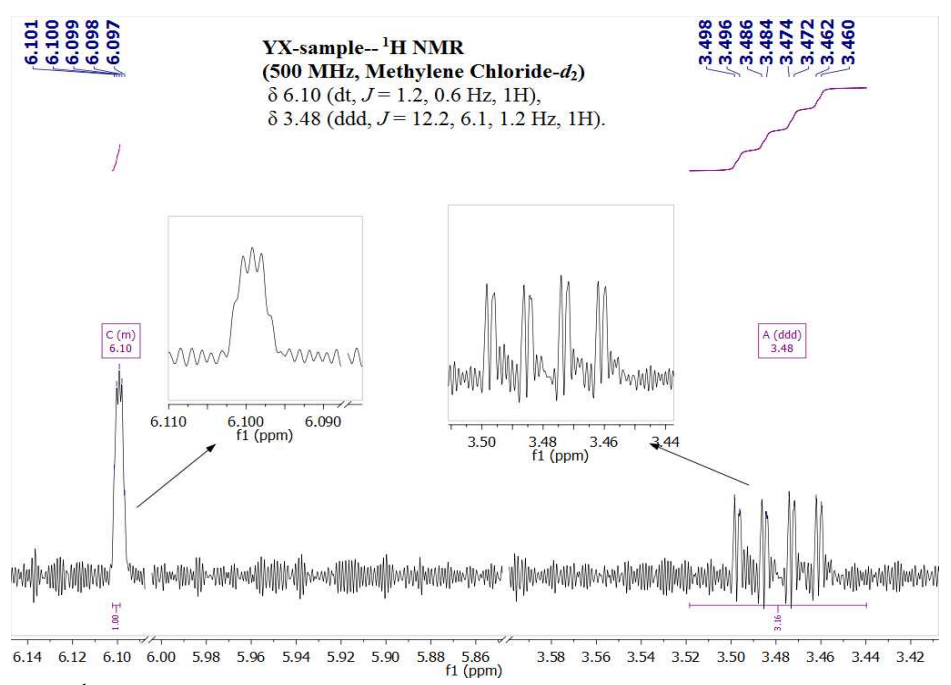

Figure $8 .{ }^{1} \mathrm{H}$ NMR data of $\mathbf{1 0}$ processed with resolution enhancement.

In the crystal structure of $\mathbf{1 0}$ previously reported (Yennawar, Singh \& Silverberg, 2014), one of the two conformations was a boat conformation, with the proton on $\mathrm{C} 2$ in a pseudo-axial positon, whereas the other was a half-chair, typical of the other structures, with the proton on $\mathrm{C} 2$ in a pseudo-equatorial position. ${ }^{1} \mathrm{H}$ NMR 
experiments were carried out in $\mathrm{CD}_{2} \mathrm{Cl}_{2}$ at room temperature and at $-80{ }^{\circ} \mathrm{C}$ to attempt observation of individual conformations (Figure 9).

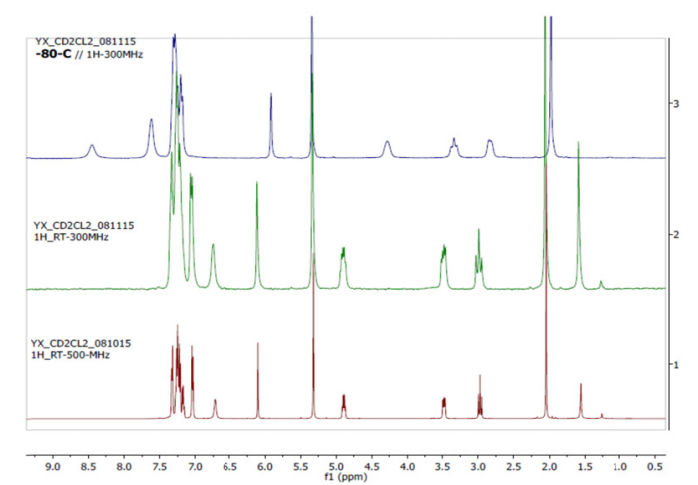

Figure 9. top-bottom: $300 \mathrm{MHz}{ }^{1} \mathrm{H}$ NMR of 10 at $-80{ }^{\circ} \mathrm{C}, 300 \mathrm{MHz}{ }^{1} \mathrm{H}$ NMR at room temperature, $500 \mathrm{MHz}{ }^{1} \mathrm{H}$ NMR at room temperature.

The crystal structure had indicated four hydrogen bonds: i) intramolecular between the N-H and the oxygen on $\mathrm{C} 4$ of the ring in the boat conformation, ii) intramolecular between the exocyclic carbonyl oxygen and an ortho-hydrogen of the phenyl ring attached to $\mathrm{C} 2$ in the half-chair conformation, iii) intermolecular between the exocyclic carbonyl oxygen of the boat and the N-H of the half-chair, and iv) intermolecular between the hydrogen on $\mathrm{C} 2$ of the boat and the oxygen on $\mathrm{C} 4$ of the half-chair.

These same interactions are suggested by the NMR experiment. Upon cooling, most of the peaks had changes in chemical shift. The NH singlet and an aromatic doublet were shifted downfield, pointing to hydrogen bond formation such as interactions i, ii, and iii. The coupling constant between the C5 proton and one of the C6 protons, $\sim 12 \mathrm{~Hz}$, was invariant with temperature. In the crystal structure, both conformations have an approximately anti-diaxial interaction between the proton on C5 and one of the protons on C6, and the coupling constant may be indicative of similar conformations in solution. The doubled doublet at $\sim 3.5 \mathrm{ppm}$ at room temperature became a doublet at $\sim 2.8 \mathrm{ppm}$ at $-80^{\circ} \mathrm{C}$, with a coupling constant of $9 \mathrm{~Hz}$. This simplification could be indicative of a move to the boat conformation, as the disappearance of hydrogen bond interaction iv would leave only a vicinal coupling between a proton on $\mathrm{C} 6$ and the proton on $\mathrm{C} 5$.

The protons on C5 ( 4.9 ppm at r.t.) and C2 (6.1 ppm at r.t.), and one of the protons on C6 (the doubled doublet at $\sim 3.5 \mathrm{ppm}$ at r.t.) moved upfield, while the other proton on C6 ( $\sim 3 \mathrm{ppm}$ at r.t.) moved downfield. The upfield shifts indicate that the $\mathrm{C} 5$ and $\mathrm{C} 2$ protons and one $\mathrm{C} 6$ proton likely moved toward a pseudo-axial position (as in the boat conformation), putting the other C6 proton pseudo-equatorial (Figure 10).

These results thus all strongly suggest that at $-80{ }^{\circ} \mathrm{C} \mathbf{1 0}$ is mainly in the boat conformation.

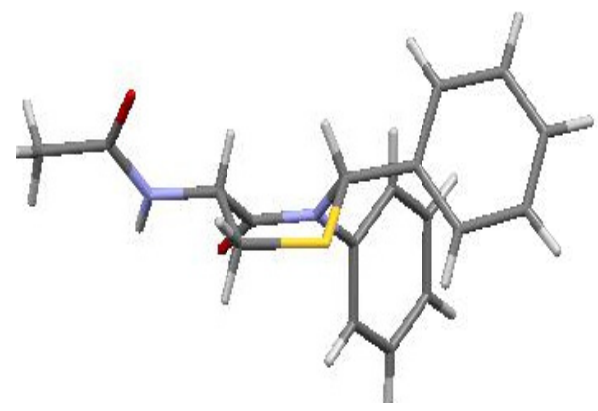

Figure 10. Boat conformation in the crystal structure of $\mathbf{1 0}$ (Yennawar, Singh \& Silverberg, 2014).

\section{$3.2^{13} \mathrm{CNMR}$}

The carbon signal for $\mathrm{C} 2$ is also common to all of the structures. Despite the differences observed in the proton signal, five-membered 13 and six-membered $\mathbf{4}$ had identical carbon-13 chemical shifts. A significant difference was observed, however, in seven-membered 12, where the signal moved downfield to 68.7 ppm, almost three ppm higher than 13 and 4. This may be useful diagnostically in distinguishing the seven-membered ring from five- or six-membered ring compounds. Compound $\mathbf{1 0}$ could also be distinguished from $\mathbf{4}$. Whereas the proton signal was downfield in cysteine-derived 10 compared to 4, the carbon signal in $\mathbf{1 0}$ was upfield by two ppm.

In contrast, the C2 signals in benzothiazinone $\mathbf{6}$ and pyridothiazinone $\mathbf{8}$ were both slightly more upfield than in $\mathbf{4}$, 
8 more so.

The ring carbonyl at $\mathrm{C} 4$ is also common to all of the compounds. Here some dramatic differences were seen. Five-membered 13 gave a resonance at 171.2, whereas six-membered $\mathbf{4}$ had a signal at 169.7, and seven-membered 12 shifted downfield to $174.2 \mathrm{ppm}$. Compounds $\mathbf{6}$ and $\mathbf{8}$ had nearly the same chemical shift, which was upfield of $\mathbf{4}$ by more than six ppm. There are two carbonyls in 10, with the signals close together, so no firm conclusions can be drawn, but they were both close to the value for $\mathrm{C} 4$ in $\mathbf{4}$.

The signal at $\mathrm{C} 4$ thus appears to be diagnostic for distinguishing five-, six-, and seven-membered rings, and for distinguishing thiazinones $(\mathbf{4}, \mathbf{1 0})$ from thiazinones with an aromatic ring fused at $\mathrm{C} 5$ and $\mathrm{C} 6(\mathbf{6}, \mathbf{8})$.

\subsection{IR}

The amide carbonyl $\mathrm{C}=\mathrm{O}$ stretching vibration at $\mathrm{C} 4$ is common to all of the structures.

A five-membered lactam is expected to give this signal at $\sim 1750-1700 \mathrm{~cm}^{-1}$ (Silverstein \& Webster, 1998), but the experimental result for $\mathbf{1 3}$ was much lower at $1668.8 \mathrm{~cm}^{-1}$.

A six-membered lactam is expected (Silverstein \& Webster, 1998) to give a signal at $\sim 1650 \mathrm{~cm}^{-1}$, and the experimental result for $\mathbf{4}$ was $1633.2 \mathrm{~cm}^{-1}$. Compound $\mathbf{1 0}$ has a second amide carbonyl on the sidechain at C5. Comparison of the spectra of $\mathbf{4}$ and $\mathbf{1 0}$ indicated that in $\mathbf{1 0}$ the ring carbonyl was at $1643.2 \mathrm{~cm}^{-1}$ and the amide sidechain at $\mathrm{C} 5$ was the absorbance at $1678.1 \mathrm{~cm}^{-1}$.

A seven-membered lactam is also expected to absorb at $\sim 1650 \mathrm{~cm}^{-1}$ (Silverstein \& Webster, 1998). The experimental result for 12 was close at $1646.6 \mathrm{~cm}^{-1}$. Thus, while the wavenumber decreased going from the five(13) to the six-membered ring (4), it increased going from the six- to the seven-membered ring (12). The differences in absorbances for $\mathbf{4}, \mathbf{1 2}$, and $\mathbf{1 3}$, suggest that the value should be diagnostic for distinguishing the thiazolidinones from the thiazinones and thiazepanones, and possibly distinguishing the latter two from each other.

Fusion of a lactam to another ring usually increases the absorbance by $20-50 \mathrm{~cm}^{-1}$ (Silverstein \& Webster, 1998). Benzothiazinone 6 gave the peak at $1682.3 \mathrm{~cm}^{-1}$, an increase of $49.1 \mathrm{~cm}^{-1}$ compared to 4 , whereas pyridothiazinone 8 had an absorbance at $1650.7 \mathrm{~cm}^{-1}$, an increase of 17.5 compared to 4 . The experimental difference of $31.6 \mathrm{~cm}^{-1}$ makes the benzothiazinone and pyridothiazinone readily distinguishable.

\section{$3.4 U V / V i s$}

Four $(\mathbf{6}, \mathbf{4}, \mathbf{1 0}$, and $\mathbf{1 3})$ compounds displayed a $\lambda_{\max }$ at $272 \mathrm{~nm}$, and $\mathbf{1 2}$ was at 268 . The only major change was in 8. Two very strong peaks of nearly equal absorbance were observed at 284 and $308 \mathrm{~nm}$. The absorbance at 308 is believed to be from the pyridine ring. Thus, UV/Vis may be diagnostic for establishing the presence of the pyridine ring.

\section{Conclusions}

Five different 2,3-diphenyl-1,3-thiaza-4-one rings were prepared and six were studied spectroscopically. The T3P synthetic method has thus far proven to be general and versatile and we are continuing to use it in ongoing studies.

Of greatest overall success in distinguishing the different compounds spectroscopically was the infrared absorbance of the $\mathrm{C} 4$ carbonyl. The ${ }^{1} \mathrm{H}$ NMR signal at $\mathrm{C} 2$ also displayed significant differences among the compounds. The ${ }^{13} \mathrm{C}$ signals at $\mathrm{C} 2$ were roughly similar, but the $\mathrm{C} 4$ signals distinguished between those that had a fused arene ring and those that didn't. The pyridothiazinone $\mathbf{8}$ gave a distinctive UV/Vis spectrum. The data collected here should be useful to researchers in identifying these types of compounds.

\section{Experimental}

General: Toluene, $N$-benzylideneaniline 2, THF, pyridine, thiosalicylic acid $\mathbf{5}$, and 3-mercaptopropionic acid $\mathbf{3}$ were purchased from Sigma-Aldrich (St. Louis, MO). $N$-acetyl-L-cysteine 9, 2-thionicotinic acid 7, and [1-(sulfanylmethyl)cyclopropyl]acetic acid $\mathbf{1 1}$ were obtained from Oakwood Products, Inc. T3P in 2-methyltetrahydrofuran (50 weight \%) was obtained from Euticals, Inc. TLC plates (silica gel GF, 250 micron, 10 × $20 \mathrm{~cm}$, catalog No. 21521) were purchased from Analtech (Newark, DE). TLC's were visualized under short wave UV, and then with $\mathrm{I}_{2}$ and then by spraying with ceric ammonium nitrate/sulfuric acid and heating. Infrared spectra were run on a Perkin-Elmer Spectrum One using a diamond-ATR attachment for the direct powder analysis (Villanova University). Spectra were taken at a resolution of $4 \mathrm{~cm}^{-1}, 16$ scans averaged. ${ }^{1} \mathrm{H}$ and ${ }^{13} \mathrm{C}$ experiments (Penn State University Park) were carried out on a Bruker 600.07-MHz Avance-III instrument using a 5-mm cryoprobe TCI 1H-13C/15N/D Z-GRD, or a Bruker Avance-III-HD 500.20-MHz instrument using 
a $5 \mathrm{~mm}$ CPPBBO BB-1H/19F/D Z-GRD probe, or a Bruker $850.24-\mathrm{MHz}$ Avance-III also using a 5 -mm cryoprobe TCI 1H-13C/15N/D Z-GRD. Samples were dissolved in $\mathrm{CDCl}_{3}$ and analyzed at RT. Low temperature NMR experiments were carried out on a Bruker DPX-300 operating at ${ }^{1} \mathrm{H}$ frequency of $300.13 \mathrm{MHz}$ using a RT BBO probe. Typical conditions for ${ }^{1} \mathrm{H}$ acquisition were $1 \mathrm{sec}$ relaxation delay, acquisition time of $2.76 \mathrm{sec}$, spectral width of $12 \mathrm{kHz}, 16$ scans. Spectra were zero-filled to $128 \mathrm{k}$ points, and multiplied by exponential multiplication (EM with $\mathrm{LB}=0.3 \mathrm{~Hz}$ ) prior to FT. For ${ }^{13} \mathrm{C}$ experiments a $2 \mathrm{sec}$ relaxation delay was employed, acquisition time of $0.9088 \mathrm{sec}$, spectral width of $36 \mathrm{kHz}, 128$ scans. Spectra were zero-filled once, and multiplied by EM with LB $=2 \mathrm{~Hz}$ prior to FT. An Applied Biosystems API 2000 Triple Quadrupole Mass Spectrometer was used to determine molecular masses by electrospray ionization (Villanova University). A $0.1 \%$ (v:v) formic acid methanol mixture containing the compound at $100 \mathrm{ppm}$ was infused at $20 \mu \mathrm{L} / \mathrm{min}$ into the electrospray source. Source and compound dependent parameters for the MS/MS product ion analysis were as follows: curtain gas $(\mathrm{CUR})=20$, nebulizer gas $(\mathrm{GAS} 1)=15$, heater gas $(\mathrm{GAS} 2)=15$, electrospray voltage $(\mathrm{IS})$ $=5500 \mathrm{~V}$, source temperature $($ TEM $)=398 \mathrm{~K}$, declustering potential $(\mathrm{DP})=40 \mathrm{~V}$, focusing potential $(\mathrm{FP})=400$ $\mathrm{V}$, entrance potential $(\mathrm{EP})=10 \mathrm{~V}$, collision energy $(\mathrm{CE})=25 \mathrm{~V}$, cell exit potential $(\mathrm{CXP})=4 \mathrm{~V}$. Ultraviolet/Visible spectroscopy was performed on a Thermo Electron Corp. Genesys 10 UV (Penn State Schuylkill). Melting points (Penn State Schuylkill) were performed on a Thomas Hoover Capillary Melting Point Apparatus (Arthur H. Thomas Co., Philadelphia, PA).

General Procedure for Preparation of Six- and Seven-membered 2,3-Diphenyl-1,3-thiaza-4-one Heterocycles: A two-necked $25 \mathrm{~mL}$ roundbottom flask was oven-dried, cooled under $\mathrm{N}_{2}$, and charged with a stir bar and $N$-benzylideneaniline $2(6 \mathrm{mmol})$. Tetrahydrofuran or 2-methyltetrahydrofuran $(2.3 \mathrm{~mL})$ was added and the solution was stirred. Pyridine $(1.95 \mathrm{~mL}, 24 \mathrm{mmol})$ was added and then the thioacid $(6 \mathrm{mmol})$ was added. Finally, 2,4,6-tripropyl-1,3,5,2,4,6-trioxatriphosphorinane-2,4,6-trioxide (T3P) in 2-methyltetrahydrofuran (50 weight percent, $7.3 \mathrm{~mL}, 12 \mathrm{mmol}$ ) was added. The reaction was stirred at room temperature and followed by TLC, then poured into a separatory funnel with dichloromethane $(20 \mathrm{~mL})$. The mixture was washed with water $(10 \mathrm{~mL})$. The aqueous was then extracted twice with dichloromethane $(10 \mathrm{~mL}$ each). The organics were combined and washed with saturated sodium bicarbonate $(10 \mathrm{~mL})$ and then saturated sodium chloride $(10 \mathrm{~mL})$. The organic was dried over sodium sulfate, concentrated under vacuum and chromatographed on $30 \mathrm{~g}$ flash silica gel, eluting with mixtures of ethyl acetate and hexanes. The crude product was further purified as indicated in previous reports or as below. X-Ray structures, melting points, and TLC retention factors have also been previously reported (Yennawar \& Silverberg, 2013, Yennawar \& Silverberg, 2014, Yennawar, Bendinsky et al., 2014, Yennawar, Singh \& Silverberg, 2014, Yennawar, Tierney \& Silverberg, 2014, Yennawar, Singh \& Silverberg, 2015).

2,3-diphenyl-2,3-dihydro-4H-1,3-benzothiazin-4-one (6): The reaction was repeated after the original report (Yennawar, Bendinsky et al., 2014). The reaction was stirred for one week (previous report was 21 hours). After chromatography, slow recrystallization from ethanol gave slightly yellow crystals $(0.6676 \mathrm{~g}, 35.1 \%$ yield), m.p. 136-137 ${ }^{\circ} \mathrm{C} .{ }^{1} \mathrm{H}$ NMR $\left(\mathrm{CDCl}_{3}\right): \delta(\mathrm{ppm}): 8.24(\mathrm{~d}, 1 \mathrm{H}, \mathrm{J}=7.3 \mathrm{~Hz}), 7.45-7.18(\mathrm{~m}, 13 \mathrm{H}), 6.07(\mathrm{~s}, 1 \mathrm{H}) .{ }^{13} \mathrm{C} \mathrm{NMR}$ $\left(\mathrm{CDCl}_{3}\right): \delta(\mathrm{ppm}): 163.8,142.5,139.5,133.3,132.4,130.4,129.5,129.2,128.5,128,3,127.7,127.2,126.6,126.4$, 125.9, 65.3. MS (m/z): $318.1(\mathrm{M}+1), 212.1,182.2,109.0$. $[\mathrm{M}+1] 318.1$ is consistent with calculated $[\mathrm{M}+\mathrm{H}]^{+}$of 318.1. IR (neat, $\mathrm{cm}^{-1}$ ): $1682.3(\mathrm{~s}), 1197.4,893.1,762.5,739.9,709.9$. UV/Vis: $\lambda_{\max }: 272 \mathrm{~nm}$ (cyclohexane).

2,3-Diphenyl-2,3,5,6-tetrahydro-4H-1,3-thiazin-4-one (4) (Yennawar, Tierney \& Silverberg, 2014): ${ }^{1} \mathrm{H}$ NMR $\left(\mathrm{CDCl}_{3}\right): \delta(\mathrm{ppm}): 7.42-7.21(\mathrm{~m}, 10 \mathrm{H}), 5.91(\mathrm{~s}, 1 \mathrm{H}), 3.06-2.87(\mathrm{~m}, 4 \mathrm{H}) .{ }^{13} \mathrm{C} \mathrm{NMR}\left(\mathrm{CDCl}_{3}\right): \delta(\mathrm{ppm}): 169.7,142.7$, 139.7, 129.2, 128.6, 128.1, 127.3, 126.8, 126.7, 65.8, 34.5, 22.7. MS (m/z): $270.3(\mathrm{M}+1), 182.2,164.1,148.2$, 120.2, 118.2, 106.1, 104.2, 92.0. [M+1] 270.3 is consistent with calculated $[\mathrm{M}+\mathrm{H}]^{+}$of 270.1 . IR (neat, $\mathrm{cm}^{-1}$ ): 2934.8, 1633.2, 1592.0, 1494.3, 1415.7, 1393.3, 1330.6, 1278.5, 1218.1, 1194.3, 774.3, 739.6, 720.4, 708.8, 690.3. UV/Vis: $\lambda_{\max }: 272 \mathrm{~nm}$ (methanol).

2,3-diphenyl-2,3-dihydro-4H-pyrido[3,2-e][1,3]thiazin-4-one (8) (Yennawar, Singh \& Silverberg, 2014): ${ }^{1} \mathrm{H}$ NMR $\left(\mathrm{CDCl}_{3}\right): \delta(\mathrm{ppm}): 8.50(\mathrm{dd}, 1 \mathrm{H}, \mathrm{J}=4.8,1.8 \mathrm{~Hz}), 8.46(\mathrm{dd}, 1 \mathrm{H}, \mathrm{J}=7.7,1.8 \mathrm{~Hz}), 7.7(\mathrm{~d}, 2 \mathrm{H}, \mathrm{J}=7.7 \mathrm{~Hz})$, $7.41(\mathrm{~m}, 2 \mathrm{H}), 7.35(\mathrm{~m}, 2 \mathrm{H}), 7.32-7.26(\mathrm{~m}, 4 \mathrm{H}), 7.21(\mathrm{~m}, 1 \mathrm{H}), 6.17(\mathrm{~s}, 1 \mathrm{H}) .{ }^{13} \mathrm{C}$ NMR $\left(\mathrm{CDCl}_{3}\right): \delta(\mathrm{ppm}): 163.4$, $156.7,152.8,142.0,139.1,137.9,129.4,128.7,128.6,127.5,126.1,125.7,121.2,65.0,37.2 . \mathrm{MS}(\mathrm{m} / \mathrm{z}): 319.3$ $(\mathrm{M}+1), 213.3,182.3,138.1 .[\mathrm{M}+1] 319.3$ is consistent with calculated $[\mathrm{M}+\mathrm{H}]^{+}$of 319.1. IR (neat, $\left.\mathrm{cm}^{-1}\right)$ : 1659.7 , 1572.6, 1491.6, 1446.7, 1394.8, 1221.4, 830.8, 762.3, 732.9, 712.2, 691.5, 655.3. UV/Vis: $\lambda_{\max }: 284$ and 308, very strong and nearly equal absorbances (methanol).

$\mathrm{N}$-[(2S,5R)-4-oxo-2,3-diphenyl-1,3-thiazinan-5-yl] acetamide (10): The reaction was repeated after the original report (Yennawar, Singh \& Silverberg, 2015). The reaction was stirred for two weeks (previous report was one day). After chromatography, fractions containing mainly the major product were combined and recrystallized 
from toluene to give $0.1575 \mathrm{~g}$. Mixed fractions that contained the major product were combined and recrystallized from acetone, yielding the major product in two crops, $0.4189 \mathrm{~g}$ and $0.1839 \mathrm{~g}$ (total of the three crops $0.7603 \mathrm{~g}, 40.8 \%)$. The three crops were combined $(0.681 \mathrm{~g})$ and recrystallized again from acetone $(0.381 \mathrm{~g}$, 55.9\% recovery). White powder. m.p.: 190-192 ${ }^{\circ} \mathrm{C} .{ }^{1} \mathrm{H}$ NMR $\left(\mathrm{CDCl}_{3}\right): \delta(\mathrm{ppm}): 7.32-7.17(\mathrm{~m}, 8 \mathrm{H}), 7.05(\mathrm{~m}, 2 \mathrm{H})$, $6.82(\mathrm{br} \mathrm{s}, 1 \mathrm{H}, \mathrm{J}=5.1 \mathrm{~Hz}, \mathrm{NH}), 6.09(\mathrm{~s}, 1 \mathrm{H}, \mathrm{C} 2), 4.99-4.95(\mathrm{dt}, 1 \mathrm{H}, \mathrm{J}=11.4,5.8 \mathrm{~Hz}, \mathrm{C} \%), 3.62-3.58(\mathrm{dd}, 1 \mathrm{H}, \mathrm{J}=$ $12.1,6.3 \mathrm{~Hz}, \mathrm{C} 6), 2.95(\mathrm{t}, 1 \mathrm{H}, \mathrm{J}=11.9 \mathrm{~Hz}, \mathrm{C} 6), 2.10\left(\mathrm{~s}, 3 \mathrm{H}, \mathrm{CH}_{3}\right) .{ }^{13} \mathrm{C} \mathrm{NMR}\left(\mathrm{CDCl}_{3}\right): \delta(\mathrm{ppm}): 170.6,170.0$, $140.1,136.7,129.0,128.8,128.5,128.2,127.9,127.7,63.8,52.2,27.6,23.3 . \mathrm{MS}(\mathrm{m} / \mathrm{z}): 327.3(\mathrm{M}+1), 285.3$, 234.2, 206.1, 182.2, 164.1. [M+1] 327.3 is consistent with calculated $[\mathrm{M}+\mathrm{H}]^{+}$of 327.1 . IR (neat, $\mathrm{cm}^{-1}$ ): 3400.4 , 3306.8, 1734.8 (w), 1678.1 (s), 1643.2 (s), 1531.9, 1490.3, 1406.4, 1356.8, 1267.9, 764.1, 733.6, 721.6, 698.7. UV/Vis: $\lambda_{\max }: 272 \mathrm{~nm}$ (methanol). ${ }^{1} \mathrm{H}$ NMR $\left(\mathrm{CD}_{2} \mathrm{Cl}_{2}\right.$, room temperature, $\left.300 \mathrm{MHz}\right): \delta(\mathrm{ppm}): 7.38-7.13(\mathrm{~m}, 8 \mathrm{H})$, $7.06(\mathrm{~d}, 2 \mathrm{H}, \mathrm{J}=6.8 \mathrm{~Hz}), 6.75(\mathrm{~s}, 1 \mathrm{H}), 6.11(\mathrm{~s}, 1 \mathrm{H}), 4.95-4.87(\mathrm{~m}, 1 \mathrm{H}), 3.52-3.48(\mathrm{dd}, 1 \mathrm{H}, \mathrm{J}=11.9,5.8 \mathrm{~Hz}), 2.99$ $(\mathrm{t}, 1 \mathrm{H}, \mathrm{J}=11.9 \mathrm{~Hz}), 2.06(\mathrm{~s}, 3 \mathrm{H}) .{ }^{1} \mathrm{H}$ NMR $\left(\mathrm{CD}_{2} \mathrm{Cl}_{2},-80{ }^{\circ} \mathrm{C}\right): \delta(\mathrm{ppm}): 8.45(\mathrm{~s}, 1 \mathrm{H}), 7.61(\mathrm{~s}, 2 \mathrm{H}), 7.31-7.18(\mathrm{~m}$, $8 \mathrm{H}), 5.91(\mathrm{~s}, 1 \mathrm{H}), 4.28(\mathrm{~s}, 1 \mathrm{H}), 3.34(\mathrm{t}, 1 \mathrm{H}, \mathrm{J}=12.1 \mathrm{~Hz}), 2.85-2.82(\mathrm{~d}, 1 \mathrm{H}, \mathrm{J}=9 \mathrm{~Hz}), 1.98(\mathrm{~s}, 3 \mathrm{H})$.

6,7-Diphenyl-5-thia-7-azaspiro[2.6]nonan-8-one (12): The reaction was repeated after the original report (Yennawar \& Silverberg, 2013). 2-Methyltetrahydrofuran was the only solvent. The reaction was stirred for four days (previous report was 20 hours). After workup to give a crude yellow liquid, crystals slowly grew. The crystals were collected by vacuum filtration and washed repeatedly with cold 2-propanol, leaving white crystals (0.424 g, 23.8\%). m.p.: $144-145{ }^{\circ} \mathrm{C} .{ }^{1} \mathrm{H}$ NMR $\left(\mathrm{CDCl}_{3}\right): \delta(\mathrm{ppm}): 7.56(\mathrm{~d}, 2 \mathrm{H}, \mathrm{J}=6.1 \mathrm{~Hz}), 7.40-7.25(\mathrm{~m}, 8 \mathrm{H})$, $6.17(\mathrm{~s}, 1 \mathrm{H}), 3.12(\mathrm{~d}, 1 \mathrm{H}, \mathrm{J}=12.2 \mathrm{~Hz}), 2.72(\mathrm{~d}, 1 \mathrm{H}, \mathrm{J}=13.4 \mathrm{~Hz}), 2.54(\mathrm{bs}, 2 \mathrm{H}), 0.9(\mathrm{~m}, 1 \mathrm{H}), 0.77-0.68(\mathrm{~m}, 2 \mathrm{H})$, 0.65-0.62 (m, 1H) ${ }^{13}{ }^{13}$ NMR $\left(\mathrm{CDCl}_{3}\right): \delta(\mathrm{ppm}): 174.2,137.3,129.3,129.1,128.2,127.9,127.8,127.5,68.7,46.2$, 17.6. MS (m/z): $310.3(\mathrm{M}+1), 204.1,188.2,182.2,146.2,129.2,120.2,69.0 .[\mathrm{M}+1] 310.3$ is consistent with calculated $[\mathrm{M}+\mathrm{H}]^{+}$of 310.1. IR (neat, $\mathrm{cm}^{-1}$ ): 2909.2, 1646.6, 1595.9, 1489.0, 1446.0, 1416.4, 1141.0, 1015.0, 914.5, 766.2, 753.3, 721.6, 709.8, 696.1. UV/Vis: $\lambda_{\max }: 268 \mathrm{~nm}$ (methanol).

2,3-diphenyl-1,3-thiazolidin-4-one (13) (Yennawar \& Silverberg, 2014, Tierney et al., 1996): ${ }^{1} \mathrm{H}$ NMR $\left(\mathrm{CDCl}_{3}\right)$ : $\delta(\mathrm{ppm}):$ 7.33-7.17 (m, 10H), $6.12(\mathrm{~s}, 1 \mathrm{H}), 4.03(\mathrm{~d}, 1 \mathrm{H}, \mathrm{J}=15.9 \mathrm{~Hz}), 3.9(\mathrm{~d}, 1 \mathrm{H}, \mathrm{J}=15.9 \mathrm{~Hz}) .{ }^{13} \mathrm{C} \mathrm{NMR}\left(\mathrm{CDCl}_{3}\right)$ : $\delta(\mathrm{ppm}): 171.3,139.7,137.7,129.3,129.11,129.08,127.3,127.1,125.8,65.8,33.7$. IR (neat, $\mathrm{cm}^{-1}$ ): 2960.6 , 1668.8, 1593.2, 1495.3, 1456.2, 1395.7, 1343.7, 1299.9, 1282.6, 1244.6, 1224.5, 1132.9, 1074.2, 899.7, 804.5, 777.6, 745.2, 717.2, 687.9, 663.9. UV/Vis: $\lambda_{\max }: 272 \mathrm{~nm}$ (methanol).

\section{Acknowledgements}

The authors sincerely thank Oakwood Products, Inc. for the gifts of 2-thionicotinic acid 7, $\mathrm{N}$-acetyl-L-cysteine $\mathbf{9}$, and [1-(sulfanylmethyl)cyclopropyl]acetic acid 11; Euticals, Inc. for the gift of T3P in 2-methyltetrahydrofuran; and Penn State Schuylkill for financial support.

\section{References}

Abhinit, M., Ghodke, M., \& Pratima, N. A. (2009). Exploring Potential Of 4-Thiazolidinone: A Brief Review. Int. J. Pharm. Pharm. Sci., 1, 47-64. http://ijppsjournal.com/Vol\%201\%20Issue\%201/122.pdf

Arya, K., Rawat, D. S., \& Sasai, H. (2012). Bronsted acidic ionic liquids: green, efficient and reusable catalyst for synthesis of fluorinated spiro [indolethiazinones/thiazolidinones] as antihistamic agents. J. Fluorine Chem., 137, 117-122. http://dx.doi.org/10.1016/j.jfluchem.2012.03.003

Arya, K., Rawat, D. S., \& Sasai, H. (2012). Zeolite supported Bronsted-acid ionic liquids: an eco approach for synthesis of spiro[indole-pyrido[3,2-e]thiazine] in water under ultrasonication. Green Chem., 14, 1956-1963. http://dx.doi.org/10.1039/c2gc35168d

Arya, K., Tomar, P., \& Singh, J. (2014). Design, synthesis and biological evaluation of novel spiro[indole-pyridothiazine] analogs as antiproliferative agents. RSC Adv., 4, 3060-3064. http://dx.doi.org/10.1039/c3ra43908a

Aissaoui, H., Boss, C., Brotschi, C., Gude, M., Gatfield, J., Siegrist, R., Sifferlen, T., \& Williams, J. T. (2012). Thiazolidin-4-One and [1,3]-Thiazinan-4-One Compounds As Orexin Receptor Antagonists. US Patent Application 2012/0088759 A1.

Badea, F., Costea, I., Iordache, F., Simion, A., \& Simion, C. (1998). Generation and trapping of 5-carbonyl-6-thioketo-1,3-cyclohexadiene. Rev. Roum. Chim., 43, 675-678. DOI: unavailable

Brown, F. C. (1961). 4-Thiazolidinones. Chem. Rev. 61, 463-521. http://dx.doi.org/10.1021/cr60213a002

Chen, Y., Wu, J., Yu, L., Zhai, D., Yi, Z., Luo, J., \& Liu, M. (2012). Preparation of 2,3-diarylthiazolidinone analogs as antitumor agents. Faming Zhuanli Shenqing, CN 102653526 A 20120905. 
Choi, H., Wang, Z., Zhu, X., He, X., Yang, K., \& Liu, H. (2008). Thiazolidinones and related compounds as inhibitors of cannabinoid receptor 1 activity, their preparation, pharmaceutical compositions, and use in therapy. PCT Int. Appl. (2008), WO 2008112674 A1 20080918.

Dandia, A., Arya, K., Sati, M., \& Gautam, S. (2004). Microwave assisted green chemical synthesis of novel spiro[indole-pyrido thiazines]: a system reluctant to be formed under thermal conditions. Tetrahedron, 60, 5253-5258. http://dx.doi.org/10.1016/j.tet.2004.04.018

Dandia, A., Saha, M., \& Rani, B. (1998). Microwave-induced Synthesis of Spiro[indoline-3,2'-[1,3]thiazine]-2,4'-diones. J. Chem. Res. (S), 360-361, 1425-1434. http://dx.doi.org/10.1039/a706678c

Dandia, A., Saha, M., \& Shivpuri, A. (1997). Improved synthesis of trifluoromethyl substituted 3-spiro indolines and 3-indolylimines under microwave irradiation. Indian J. Chem. Techn., 4, 201-205.

Dandia, A., Saha, M., \& Taneja, H. (1998). Improved one-pot synthesis of 3-spiroindolines under microwave irradiation. Phosphorus, Sulfur and Silicon and the Related Elements, 139, 77-85. http://dx.doi.org/10.1080/10426509808035679

Dandia, A., Sharma, C. S., \& Saha, M. (1998). Facile synthesis of some new fluorine containing spiro[3H-indole-3,2'-tetrahydro-1,3-thiazine].2,4'(1H)-diones. Phosphorus, Sulfur and Silicon and the Related Elements, 139, 57-66. http://dx.doi.org/10.1080/10426509808035677

Dandia, A., Singh, R., \& Arya, K. (2004). Microwave induced dry-media synthesis of spiro[indole-thiazolidinones/thiazinones] as potential antifungal and antitubercular agents and study of their reactions. Phosphorus, Sulfur and Silicon and the Related Elements, 179, 551-564. http://dx.doi.org/10.1080/10426500490422209

Dandia, A., Singh, R., \& Saini, D. (2013). Ionic liquid-mediated three-component synthesis of fluorinated spiro-thiazine derivatives and their antimycobacterial DNA cleavage activities. J. Chem. Sci. (Bangalore, India), 125, 1045-1053. http://dx.doi.org/10.1007/s12039-013-0493-8

Dandia, A., Singh, R., Merienne, C., Morgant, G., \& Loupy, A. (2003). Solvent-free one-pot synthesis and crystal structure of a spiro[indole-thiazine]. Sulfur Lett., 26, 201-207. http://dx.doi.org/10.1080/02786110310001637617

Dunetz, J. R., Xiang, Y., Baldwin, A., \& Ringling, J. (2011). General and Scalable Amide Bond Formation with Epimerization-Prone Substrates Using T3P and Pyridine. Org. Lett., 13, 5048-5051. http://dx.doi.org/10.1021/ol201875q

Graul, A., Leeson, P., \& Castañer, J. (1999). Omapatrilat. Antihypertensive, Treatment of heart failure, ACE inhibitor, Neutral endopeptidase inhibitor. Drug. Future 24, 269. https://journals.prous.com/journals/servlet/xmlxsl/pk_journals.xml_toc_pr?p_JournalID=2\&p_IssueID=348

Hamama, W. S., Ismail, M. A., Shaaban, S., \& Zoorob, H. H. (2008). Progress in the chemistry of 4thiazolidinones. J. Heterocyclic Chem., 45, 939-956. http://dx.doi.org/10.1002/jhet.5570450401

Jain, A. K., Vaidya, A., Ravichandran, V., Kashaw, S. K., \& Agrawal, R. A. (2012). Recent developments and biological activities of thiazolidinone derivatives: A review. Bioorg. Med. Chem., 20, 3378-3395. http://dx.doi.org/10.1016/j.bmc.2012.03.069

Joshi, K. C., Dandia, A., \& Ahmed, N. (1986). Studies in spiroheterocycles. Part IX. New elegant synthesis and reactions of some novel fluorine-containing spiro[3H-indole-3,2'-tetrahydro-1,3-thiazine]-2,4'(1H)-diones. Heterocycles, 24, 2479-85. http://dx.doi.org/10.3987/R-1986-09-2479

Joshi, K. C., Jain, R., \& Nishith, S. (1991). Reactions of 3-arylimino-2H-indol-2-ones with $o$-mercaptobenzoic acid and salicylic acid: synthesis of novel spiro[2H-1,3-benzothiazine-2,3'-[3H]indole]-2,4(1H,3H)-diones. J. Indian Chem. Soc., 68, 625-7. http://dx.doi.org/unavailable

Kamel, M. M., Ali, H. I., Anwar, M. M., Mohamed, N. A., \& Soliman, A. M. M. (2010). Synthesis, antitumor activity and molecular docking study of novel Sulfonamide-Schiff's bases, thiazolidinones, benzothiazinones and their C-nucleoside derivatives. Eur. J. Med. Chem., 45, 572-580. http://dx.doi.org/10.1016/j.ejmech.2009.10.044

Kitsiou, C., Unsworth, W. P., Coulthard, G., \& Taylor, R. J. K. (2014). Substrate scope in the direct imine acylation of ortho-substituted benzoic acid derivatives: the total synthesis $( \pm)$-cavidine. Tetrahedron 70 , 7172-7180. http://dx.doi.org/10.1016/j.tet.2014.04.066 
Kollenz, G., \& Ziegler, E. (1970). Synthesen von Heterocyclen, 140. Mitt.: Zur Chemie cyclischer Carbonate. Monatsh. Chem. 1012 97-101. http://dx.doi.org/10.1007/BF00907530

Loev, B. (1963). 2,3-Dihydro-4H-1,3-benzothiazinones-4. J. Org. Chem., 28, 2160. http://dx.doi.org/10.1021/jo01043a516

Metwally, N. H. (2013). 2-Keto-3-mercaptocinchoninic acids as precursors for novel thiazino[6,5-c]quinoline-1,5-dione derivatives. Synthetic Commun., 43, 398-405. http://dx.doi.org/10.1080/00397911.2011.601838

Mogilaiah, K., Reddy, P. R., \& Rao, R. B. (1999). Synthesis and antimicrobial activity of 1,8-naphthyridinyl-4-thiazolidinones/1,3-thiazin-4-ones/2-azetidinones. Indian J. Chem. B, 38B, 495-500. http://nopr.niscair.res.in/handle/123456789/16405

Oae, S., \& Numata, T. (1974). A novel cyclization reaction of o-carboxyphenyl and o-carbamoylphenyl sulfoxides: Formation of benzoxathiane, dihydrobenzothiazine and benzoisothiazoline derivatives. Tetrahedron, 30, 2641-2646. http://dx.doi.org/10.1016/S0040-4020(01)97423-X

Ottenheijm, H. C. J., Hulshof, J. A. M., \& Nivard, R. J. F. (1975). Approaches to analogs of anhydrogliotoxin. 3. Synthesis of a desthiomethylene analog. J. Org. Chem., 40, 2147-2150. http://dx.doi.org/10.1021/jo00903a002

Ottenheijm, H. C. J., Vermeulen, N. P. E., \& Breuer, L. F. J. (1974). Synthesis of anhydrogliotoxin analogs. Synthesis of thiazoloindolone derivatives. Liebigs Ann. Chem., 206-212. http://dx.doi.org/10.1002/jlac.197419740208

Ponci, R., Baruffini, A., \& Gialdi, F. (1963). Derivatives of Dihydro-1,3-benzothiazine-4-one. Farmaco-Ed. Sci. 18, 653-657.

Prabhakar, Y. S., Solomon, V. R., Gupta, M. K., \& Katti, S. B. (2006). QSAR Studies on Thiazolidines: A Biologically Privileged Scaffold. Top. Heterocyclic Chem. 4, 161-249. http://dx.doi.org/10.1007/7081_021

Qu, H., Zhang, R., Hu, Y., Ke, Y., Gao, Z., \& Xu, H. (2013). Synthesis and antifungal activities of 2-(N-arylsulfonylindol-3-yl)-3-aryl-1,3-thiazinan-4-ones. $\quad$ Z. $\quad$ Naturforsch. $\quad$ C, $68, \quad 77-81$. http://dx.doi.org/10.1515/znc-2013-3-401

Rajopadhye, M., \& Popp, F. $\quad$ D. $\quad$ (1985). Synthesis of spiro[3H-indole-3,2'-tetrahydro-1,3-thiazine]-2,4'(1H)-diones. J. Heterocyclic Chem., 22, 93-96. http://dx.doi.org/10.1002/jhet.5570220124

Robl, J. A., Sun, C. Q., Stevenson, J., Ryono, D. E., Simpkins, L. M., Cimarusti, M. P., \& Trippodo, N. C. (1997). Dual Metalloprotease Inhibitors: Mercaptoacetyl-Based Fused Heterocyclic Dipeptide Mimetics as Inhibitors of Angiotensin-Converting Enzyme and Neutral Endopeptidase. J. Med. Chem., 40, 1570-1577. http://dx.doi.org/10.1021/jm970041e

Ryabukhin, Y. I., Korzhavina, O. B., \& Suzdalev, K. F. (1996). Chemistry of 1,3-Thiazin-4-ones and Their Derivatives. Adv. Heterocyclic Chem., 66, 131-191. http://dx.doi.org/10.1016/s0065-2725(08)60306-2

Silverstein, R. M., \& Webster, F. X. (1998). Spectrometric Identification of Organic Compounds $\left(6^{\text {th }}\right.$ ed.). New York, NY: John Wiley \& Sons, Inc.

Singh, S. P., Parmar, S. P., Raman, K., \& Stenberg, V. I. (1981). Chemistry and Biological Activity of Thiazolidinones. Chem. Rev., 81, 175-203. http://dx.doi.org/10.1021/cr00042a003

Srivastava, T., Haq, W., \& Katti, S. B. (2002). Carbodiimide mediated synthesis of 4-thiazolidinones by one-pot three-component $\quad$ condensation. $\quad$ Tetrahedron, $\quad 58, \quad 7619-7624$. http://dx.doi.org/10.1016/s0040-4020(02)00866-9

Surrey, A. R. (1947). The Preparation of 4-Thiazolidones by the Reaction of Thioglycolic Acid with Schiff Bases. J. Am. Chem. Soc. 69, 2911-2912. http://dx.doi.org/10.1021/ja01203a507

Surrey, A. R., Webb, W. G., \& Gesler, R. M. (1958). Central Nervous System Depressants. The Preparation of Some 2-Aryl-4-metathiazanones. J. Am. Chem. Soc., 80, 3469-3471. http://dx.doi.org/10.1021/ja01546a065

Tabrizchi, R. (2001). Omapatrilat. Bristol-Myers Squibb. Curr. Opin. Investig. D., 2, 1414-1422. PMID: 11890357

Tanaka, R., \& Hirayani, H. (2005). Structure of Chlormezanone. X-Ray Structure Analysis Online, 21 , x57. http://www.jsac.or.jp/cgi-bin/xraystruct/toc/21/4/ 
Tierney, J. (1989). The Formation of 2,3-Disubstituted Thiazolidin-4-ones from $S$ - $\alpha$-Aminomercaptoacetic Acid Derivatives. J. Heterocyclic Chem., 26, 997-1001. http://dx.doi.org/10.1002/jhet.5570260419

Tierney, J., Houghton, G., Sanford, K., Mascavage, L., McCoy, M., Findeisen, A., \& Kilburn, J. (1996). Effects and Conformational Analysis of Some Substituted 2,3-Diphenyl-1,3-thiazolidin-4-ones. Magn. Reson. Chem., 34, 573-576.

Tripathi, A. C.., Gupta, S. J., Fatima, G. N., Sonar, P. K., Verma, A., \& Saraf, S. K. (2014). 4-Thiazolidinones: The advances continue. Eur. J. Med. Chem., 72, 52-77. http://dx.doi.org/10.1016/j.ejmech.2013.11.017

Unsworth, W. P., Kitsiou, C., \& Taylor, R. J. K. (2013). Direct Imine Acylation: Rapid Access to Diverse Heterocyclic Scaffolds. Org. Lett. 15, 258-261. http://dx.doi.org/10.1021/ol303073b

Woolston, C. R. J., Lee, J. B., \& Swinbourne, F. J. (1993). An Infra-red Spectroscopic Study of Some Substituted 1,3-Thiazolidin-4-ones. Phosphorus, Sulfur, and Silicon and the Related Elements, 78, 223-235. http://dx.doi.org/10.1080/10426509308032438

Woolston, C. R. J., Lee, J. B., \& Swinbourne, F. J. (1993). Carbon-13 NMR Investigation of Some Substituted 1,3-Thiazolidin-4-ones. Magn. Reson. Chem., 31, 348-351. http://dx.doi.org/10.1002/mrc.1260310407

Woolston, C. R. J., Lee, J. B., \& Swinbourne, F. J., Thomas, W. A. (1992). Proton NMR Investigation of Some Substituted 1,3-Thiazolidin-4-ones. Magn. Reson. Chem., 30, 1075-1078. http://dx.doi.org/10.1002/mrc.1260301109

Yennawar, H. P., Tierney, J., \& Silverberg, L. J. (2014). 2,3-diphenyl-1,3-thiazolidin-4-one. Acta Crystallogr. E, E70, o847. http://dx.doi.org/10.1107/S1600536814015128

Yennawar, H. P., Bendinsky, R. V., Coyle, D. J., Cali, A. S., \& Silverberg, L. J. (2014). 2,3-diphenyl-2,3-dihydro-4H-1,3-benzothiazin-4-one. Acta Crystallogr. E, E70, 0465. http://dx.doi.org/10.1107/S1600536814005881

Yennawar, H. P., \& Silverberg, L. J. (2013). 6,7-diphenyl-5-thia-7-azaspiro[2.6]nonan-8-one. Acta Crystallogr. E, E69, o1659. http://dx.doi.org/10.1107/S1600536813027979

Yennawar, H. P., Silverberg, L. J. (2014). 2,3-Diphenyl-2,3,5,6-tetrahydro-4H-1,3-thiazin-4-one. Acta Crystallogr. E, E70, o133. http://dx.doi.org/10.1107/S1600536814000324

Yennawar, H. P., Singh, H., \& Silverberg, L. J. $\quad$ (2014). 2,3-diphenyl-2,3-dihydro-4H-pyrido[3,2-e][1,3]thiazin-4-one. Acta Crystallogr. E, E70, 0638. http://dx.doi.org/10.1107/S1600536814009714

Yennawar, H. P., Singh, H., \& Silverberg, L. J. (2015). Crystal Structure of N-[(2S,5R)-4-oxo-2,3-diphenyl-1,3-thiazinan-5-yl]acetamide 0.375 hydrate. Acta Crystallogr. E, E71, 62-64. http://dx.doi.org/10.1107/S2056989014026425

Yi, Z., Tong, Weiguang, Z., Dong, L., Li, Wu, J., Chen, Y., \& Liu, M. (2012). 2,3-Diarylthiazolinone compounds as angiogenesis inhibitors and their preparation, pharmaceutical compositions and use in the treatment of diseases. Faming Zhuanli Shenqing, CN 102786493 A 20121121.

Zarghi, A, Zebardast, T., Daraie, B., \& Hedayati, M. (2009). Design and synthesis of new 1,3-benzthiazinan-4-one derivatives as selective cyclooxygenase (COX-2) inhibitors. Bioorg. Med. Chem., 17, 5369-5373. http://dx.doi.org/10.1016/j.bmc.2009.06.056

Zhou, H., Liu, A., Li, X., Ma, X., Feng, W., Zhang, W., \& Yan, B. (2008). Microwave-Assisted Fluorous Synthesis of 2-Aryl-Substituted 4-Thiazolidinone and 4-Thiazinanone Libraries. J. Comb. Chem., 10, 303312. http://dx.doi.org/10.1021/cc700164u

\section{Copyrights}

Copyright for this article is retained by the author(s), with first publication rights granted to the journal.

This is an open-access article distributed under the terms and conditions of the Creative Commons Attribution license (http://creativecommons.org/licenses/by/3.0/). 